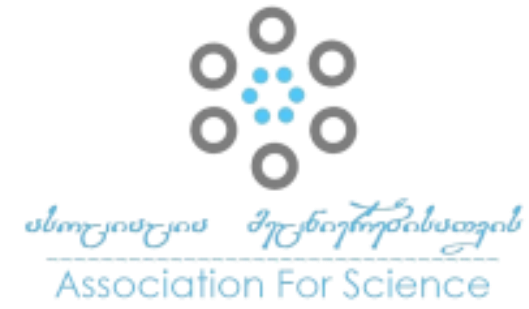

Association For Science

\section{Georgian Scientists}

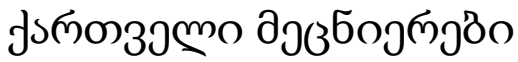

Vol. 3 Issue 4, 2021

https://doi.org/10.52340/gs.2021.11.03

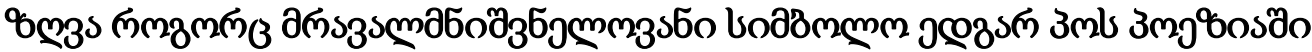

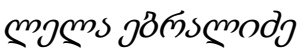

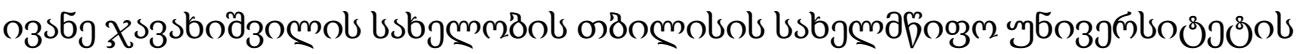

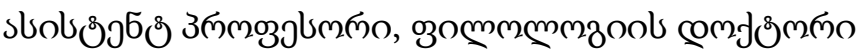

\section{https://orcid.org/0000-0003-0802-4085}

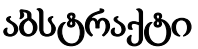

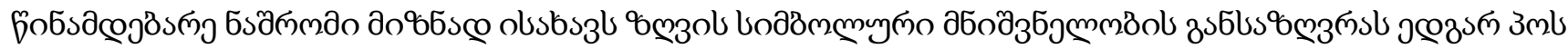

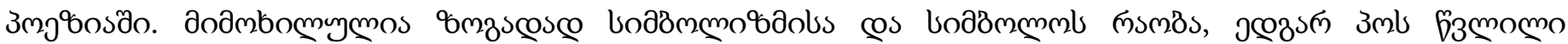

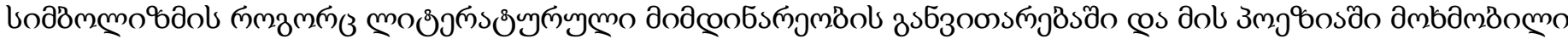

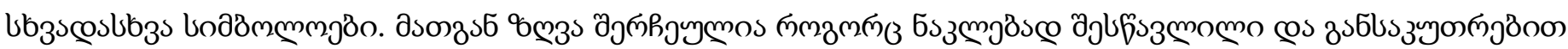

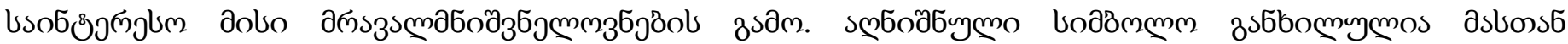

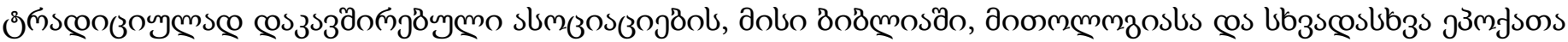

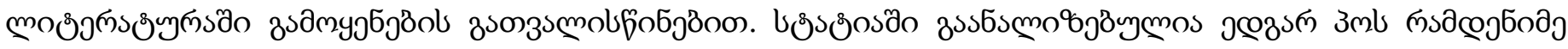

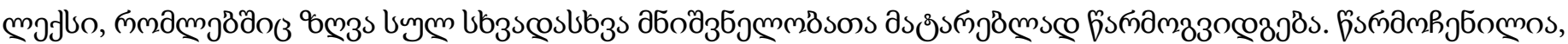

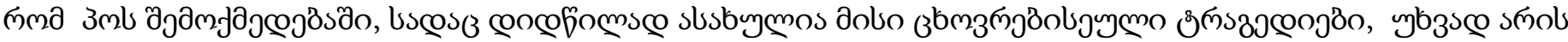

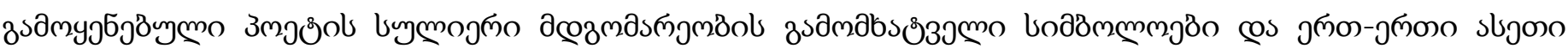

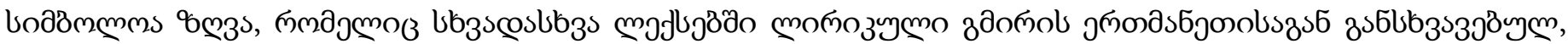

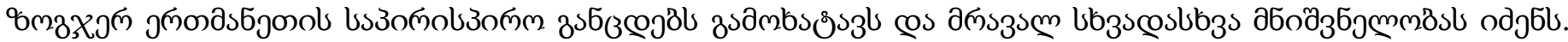

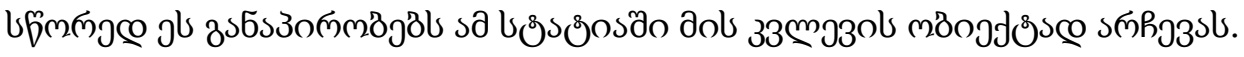

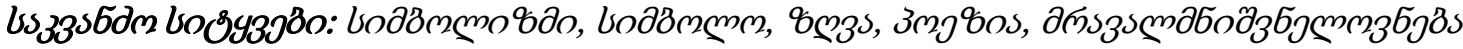




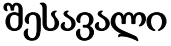

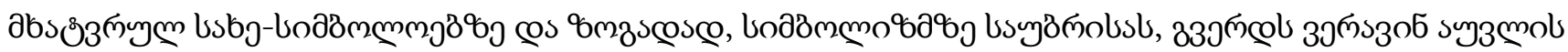

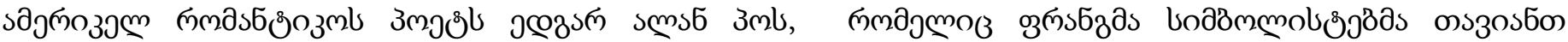

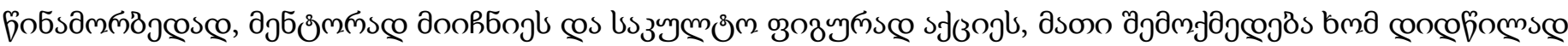

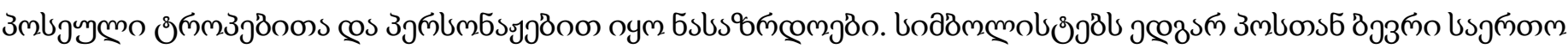

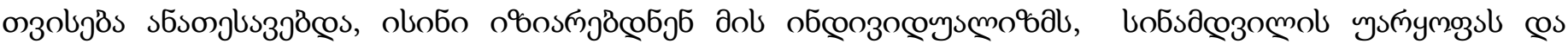

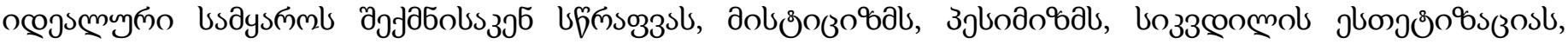

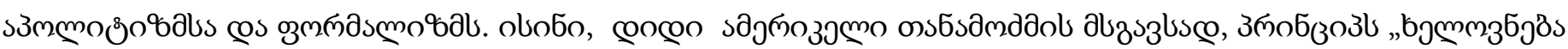

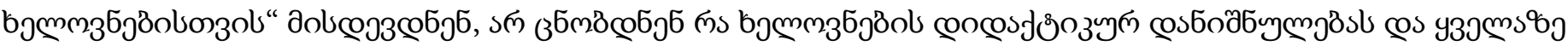

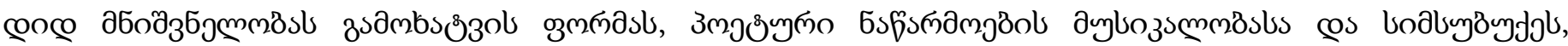

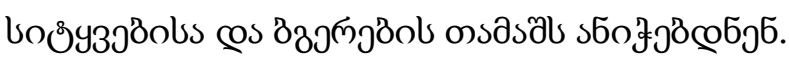

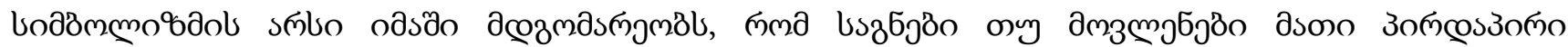

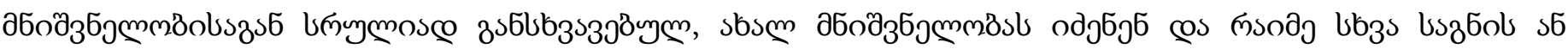

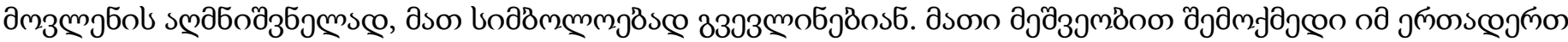

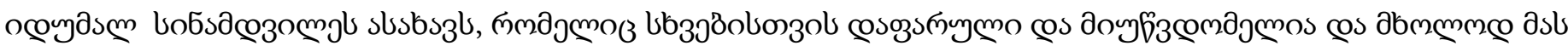
дsmyдd дs rsf̧звmas.

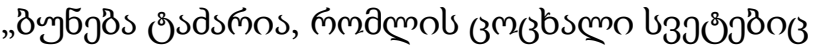

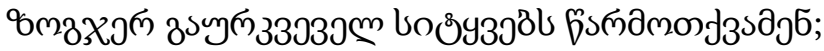

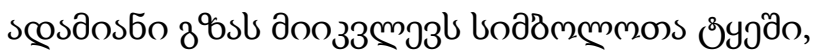

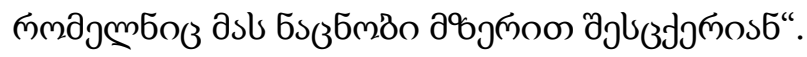

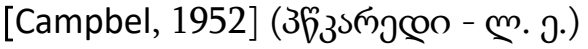

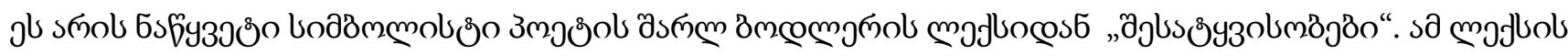

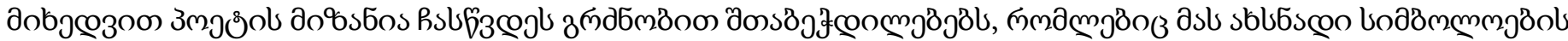

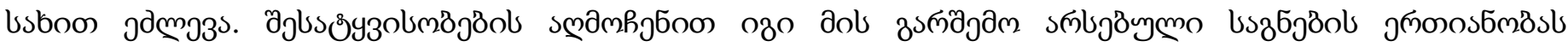

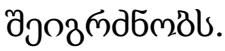

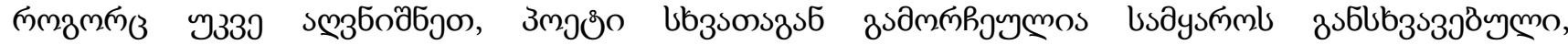

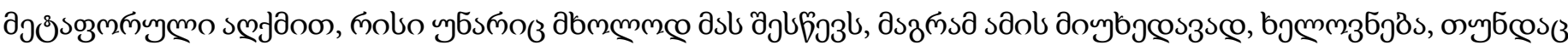

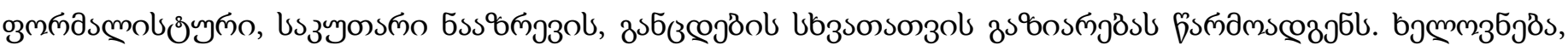

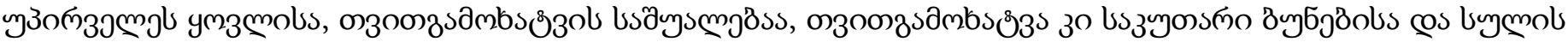

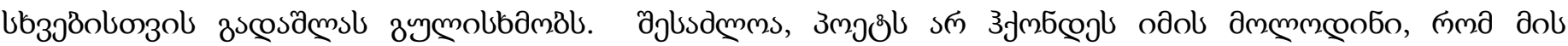

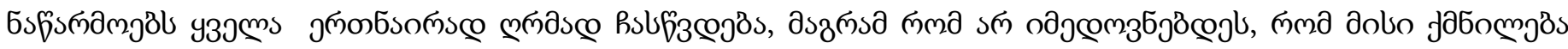

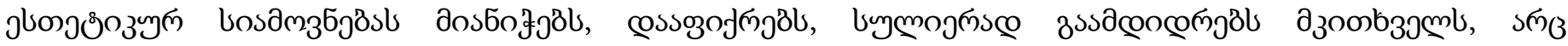

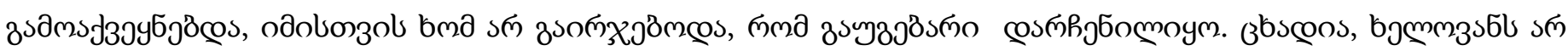

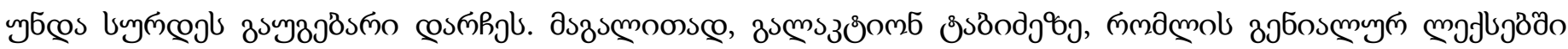

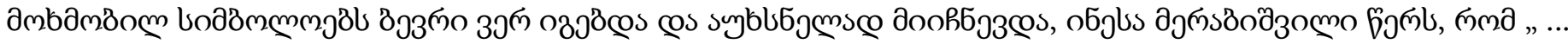




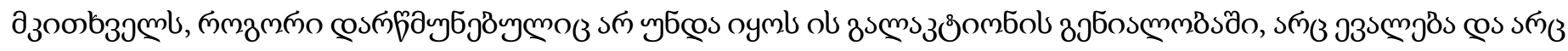

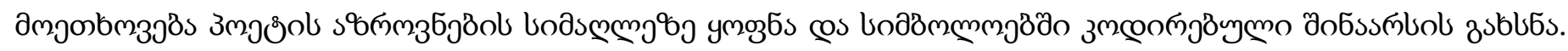

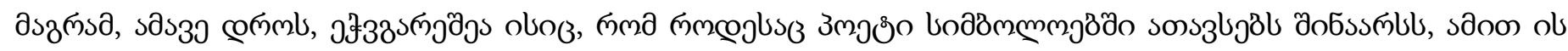

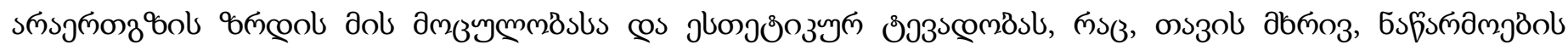

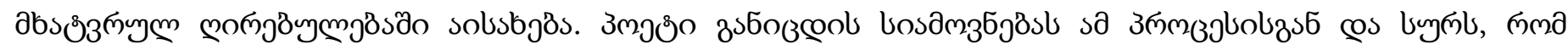

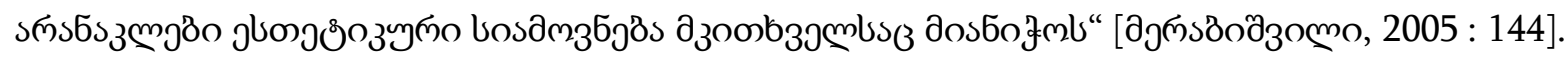

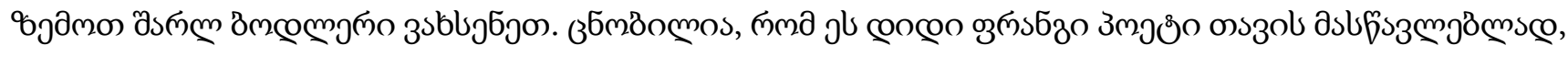

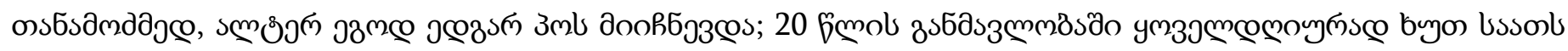

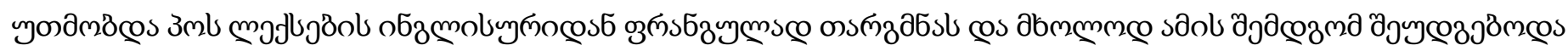

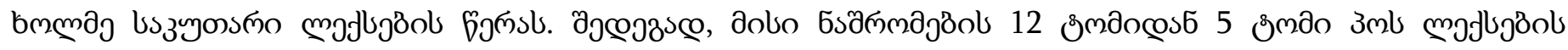

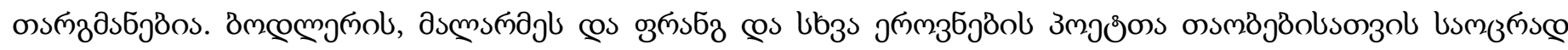

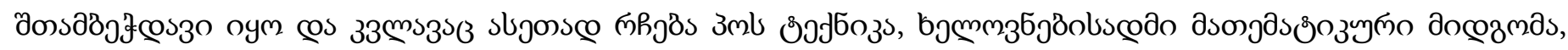

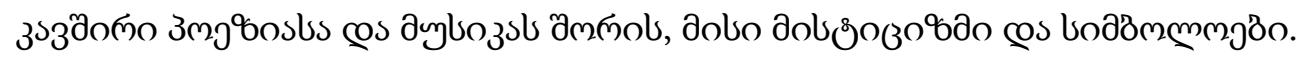

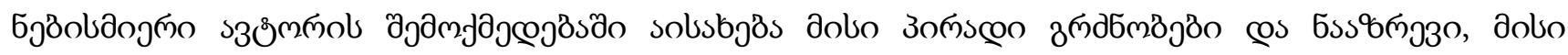

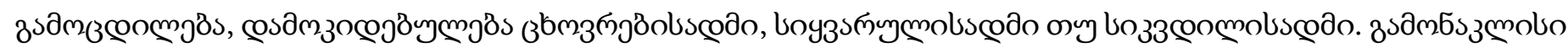

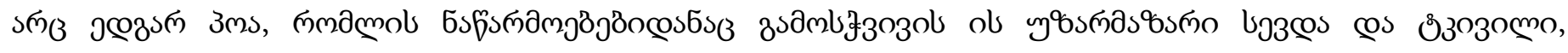

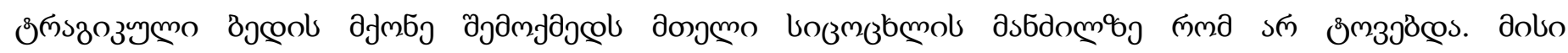

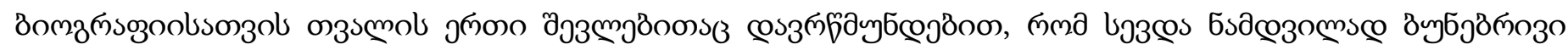

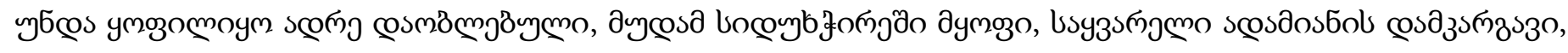

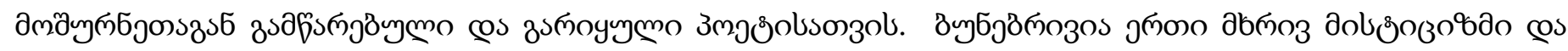

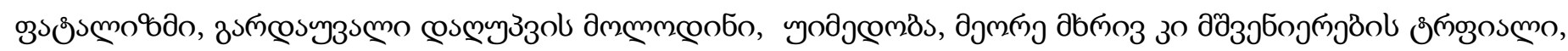

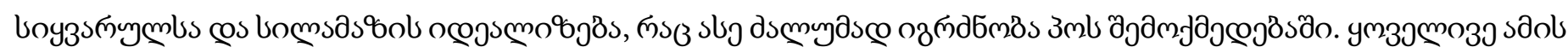

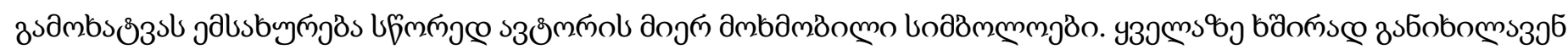

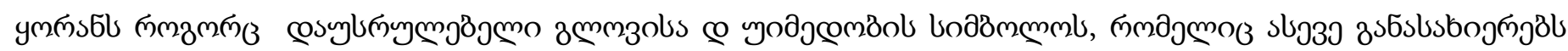

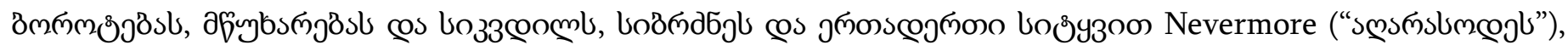

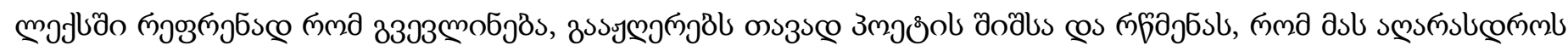

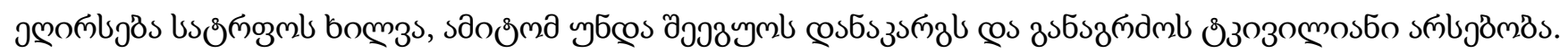

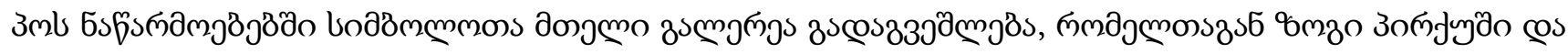

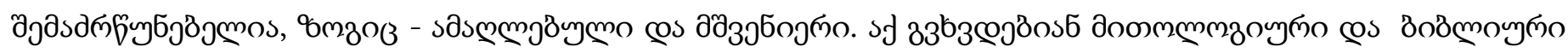

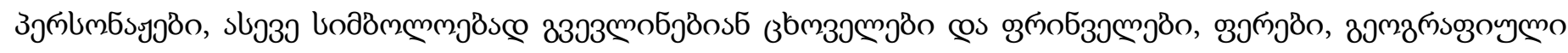

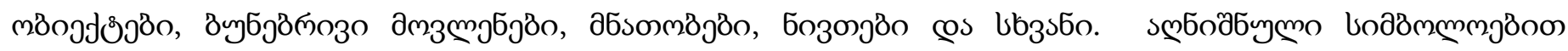

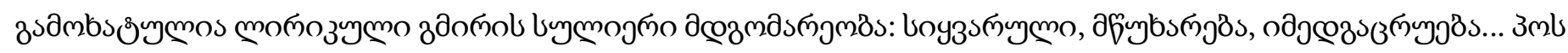

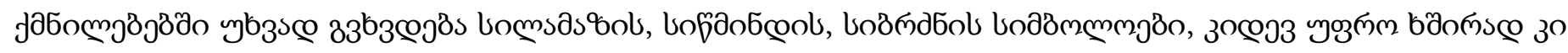

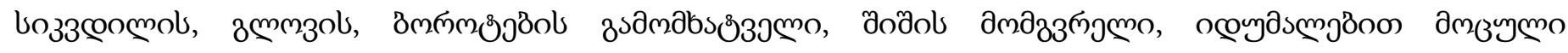

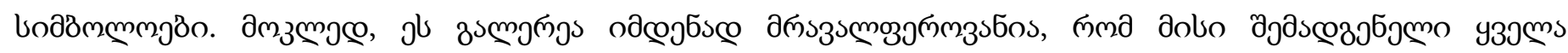

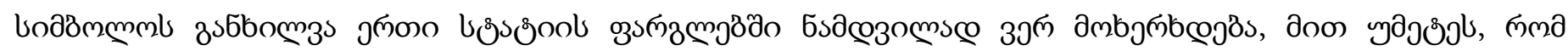

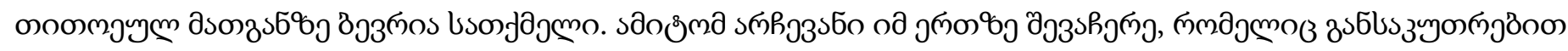

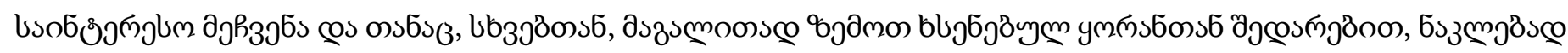

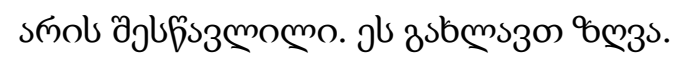




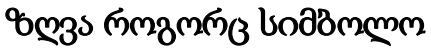

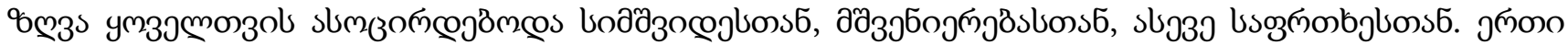

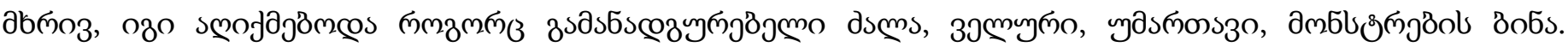

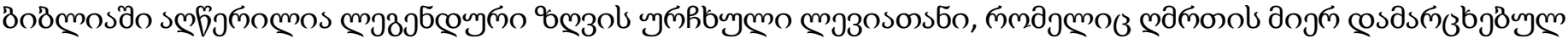

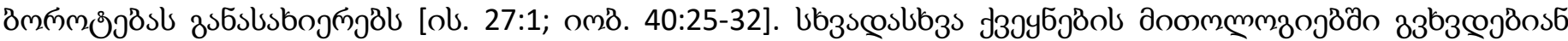

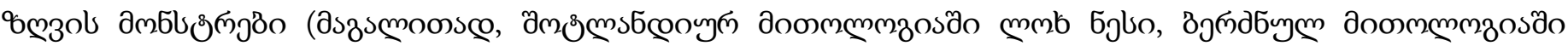

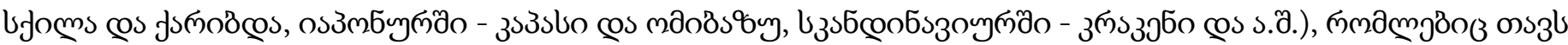

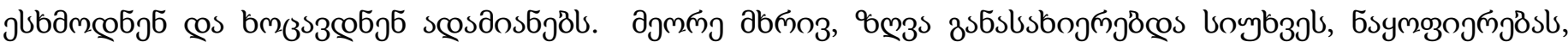

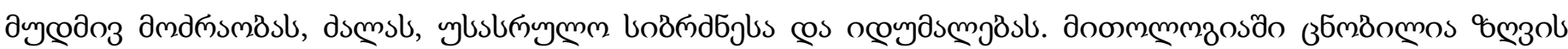

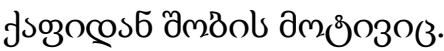

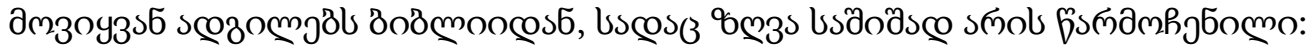

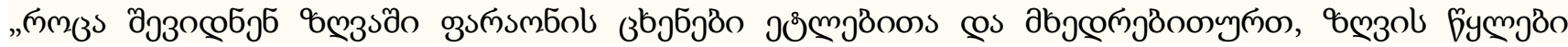

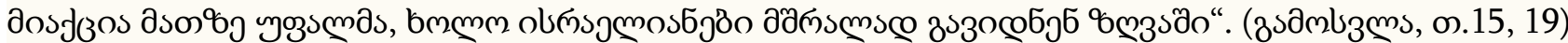

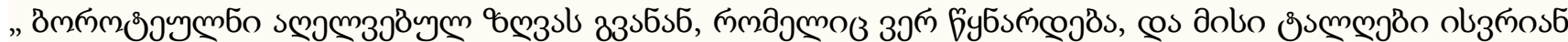
msojbs @s ossmsbl“. (jusos, on. 57, 20)

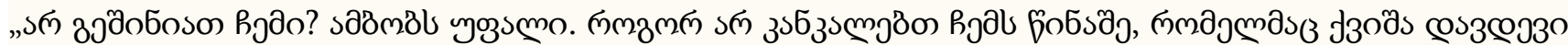

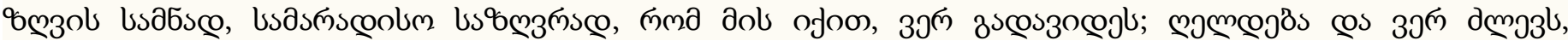

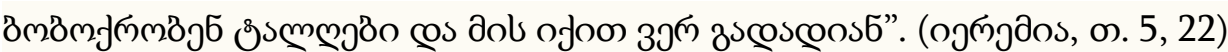

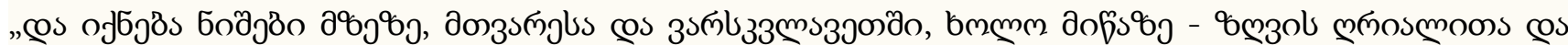

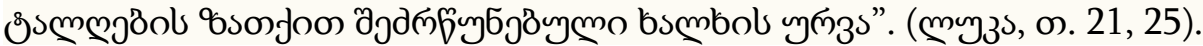

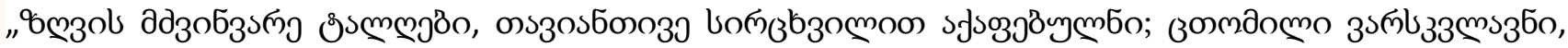

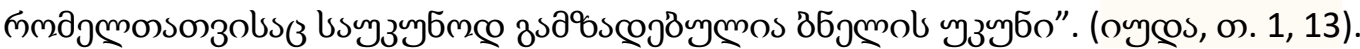

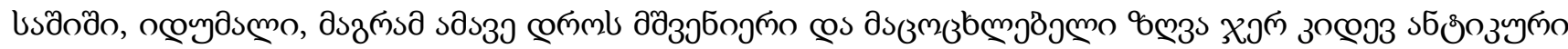

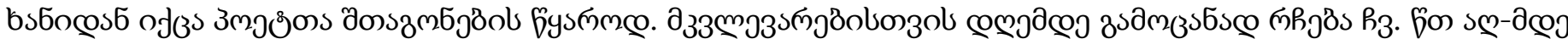

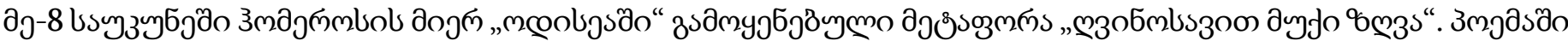

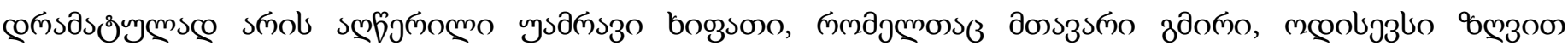

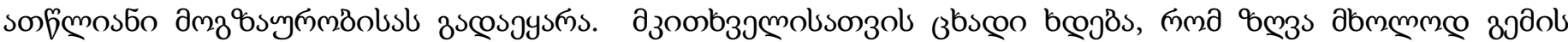

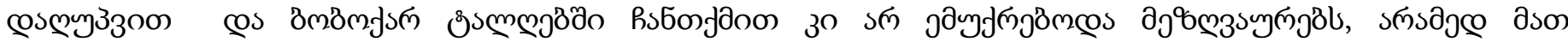

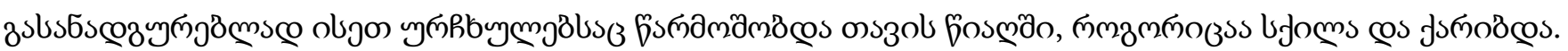

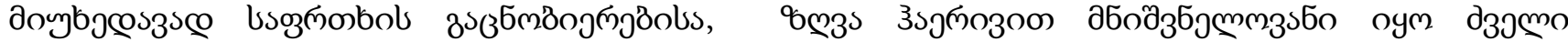

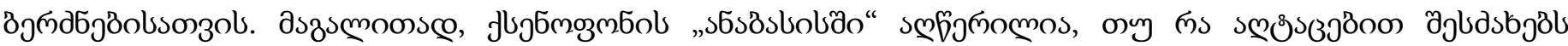

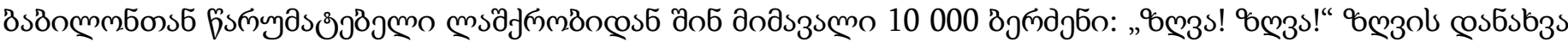

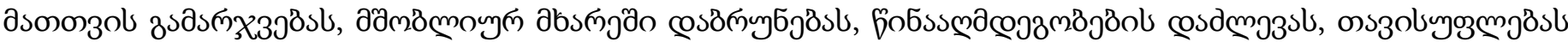
бoð6şง. 


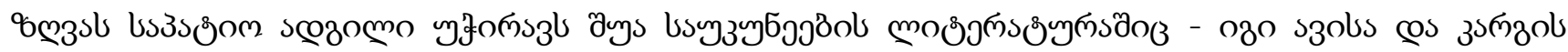

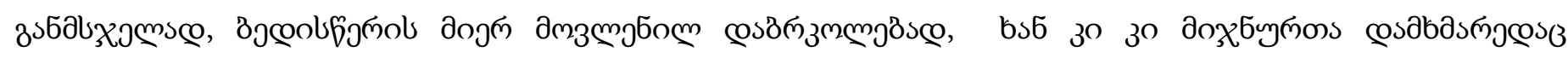

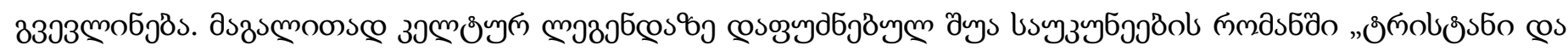

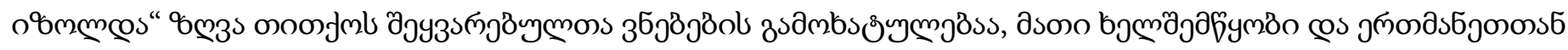

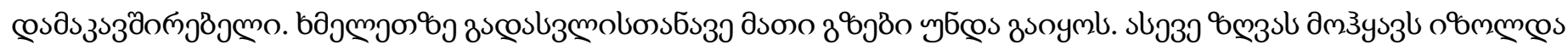

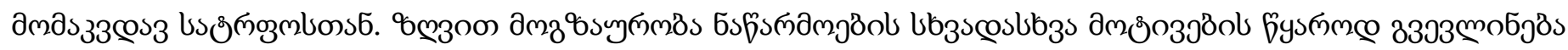

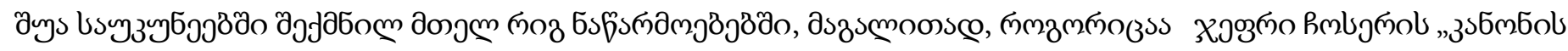

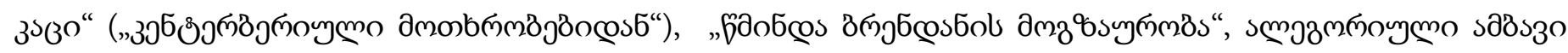

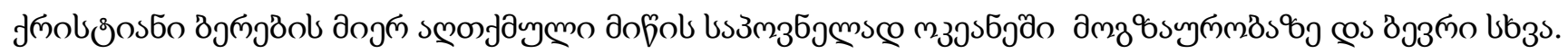

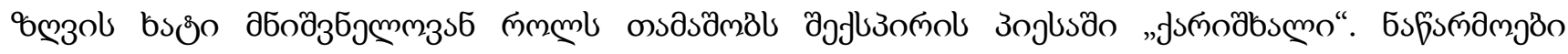

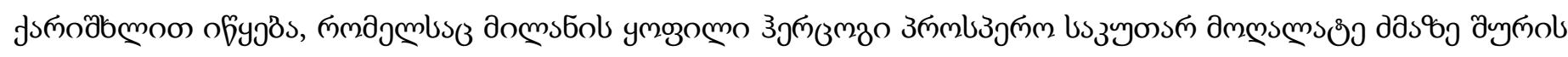

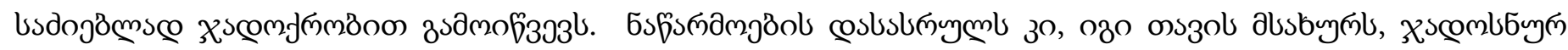

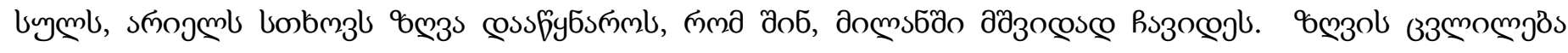

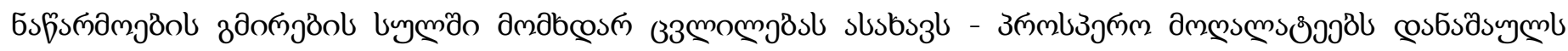

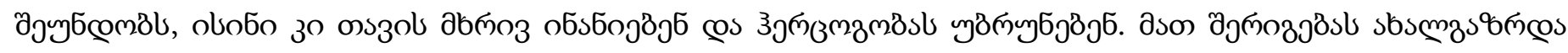

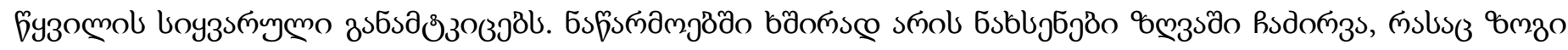

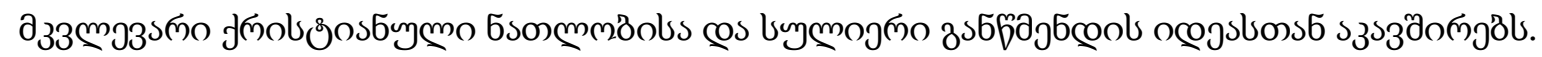

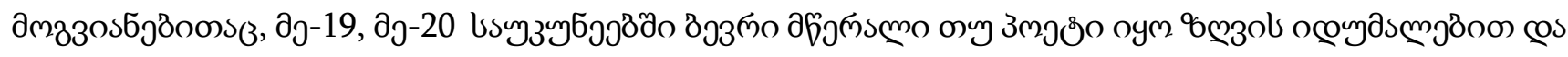

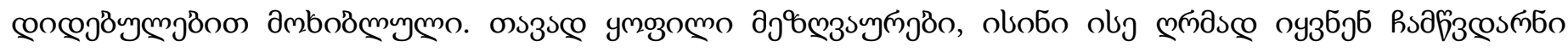

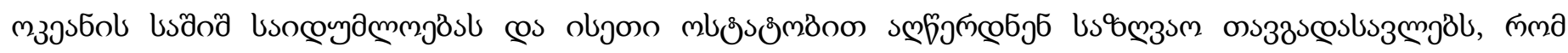

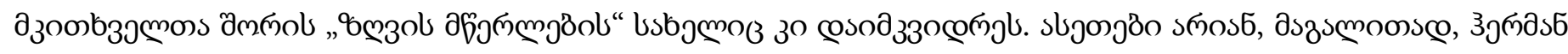

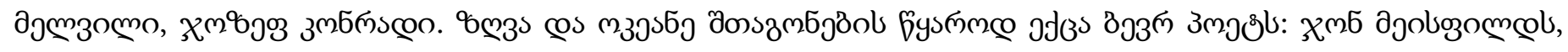

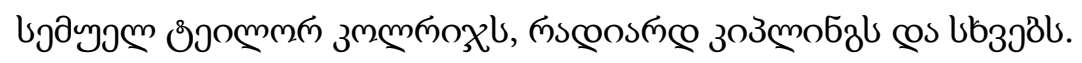

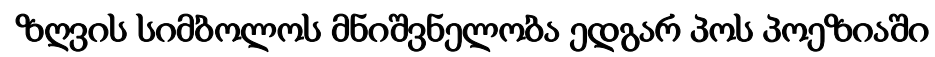

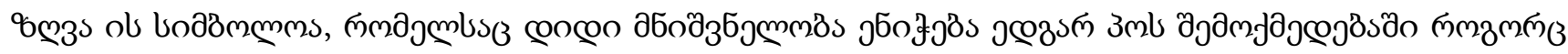

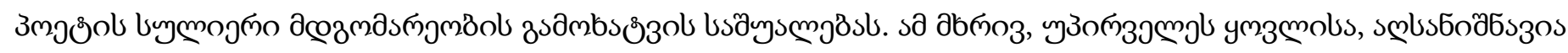

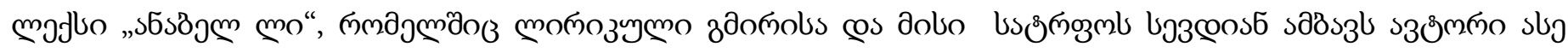
обу9ฎ:

It was many and many a year ago,

In a kingdom by the sea, [An Anthology... 1972:473]

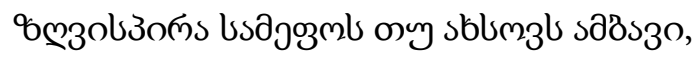

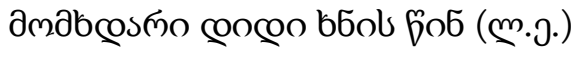

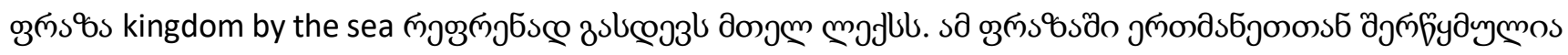

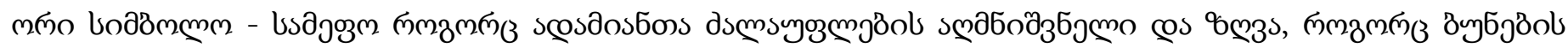




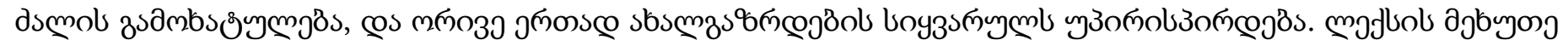

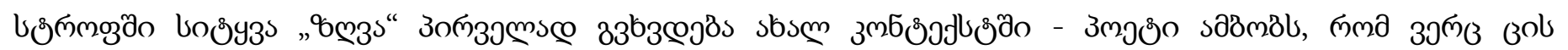

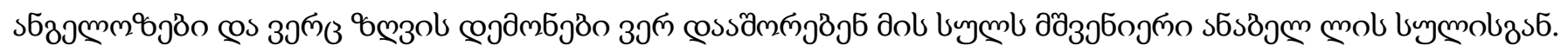

\author{
And neither the angels in Heaven above \\ Nor the demons down under the sea \\ Can ever dissever my soul from the soul \\ Of the beautiful Annabel Lee; [An Anthology... 1972:474]

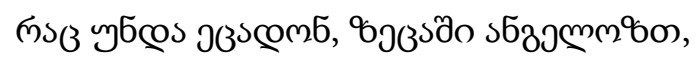

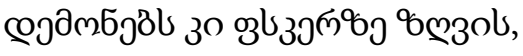

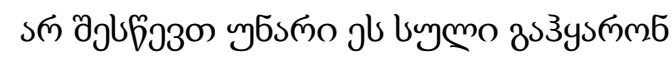

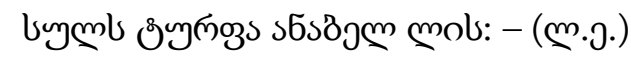

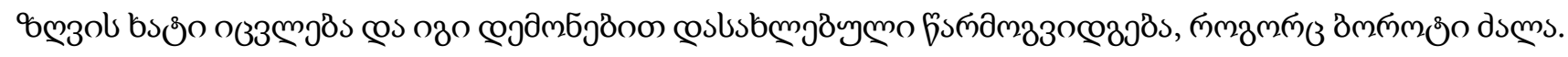

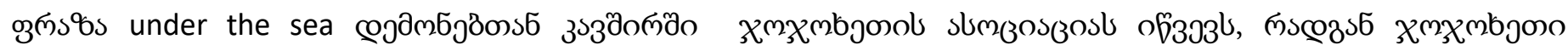

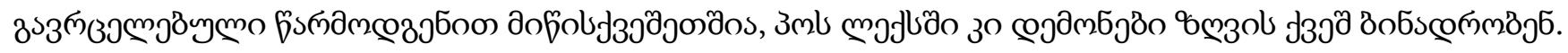

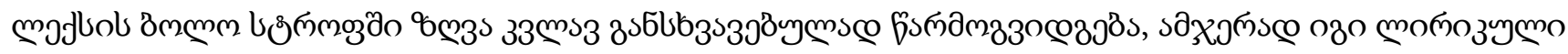

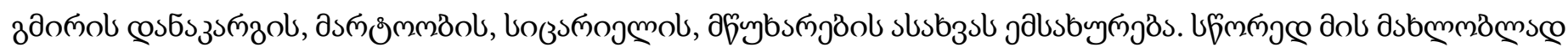

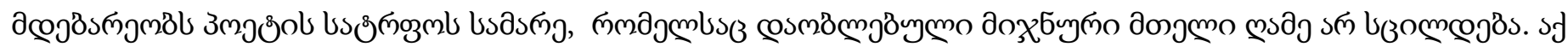

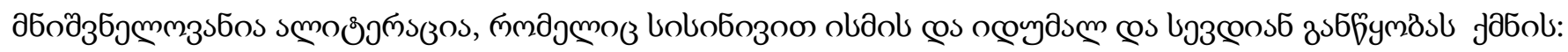

In her sepulchre there by the sea-

In her tomb by the sounding sea. [An Anthology... 1972:474]

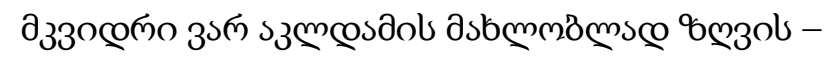

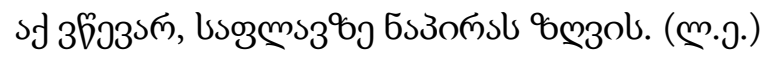

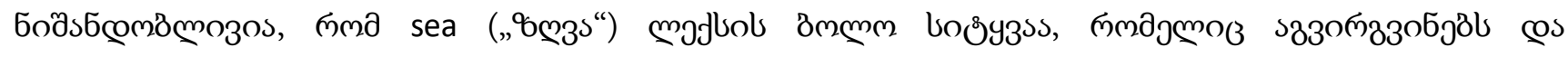

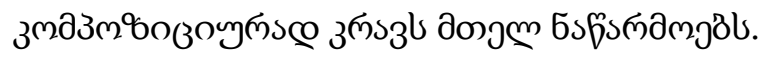

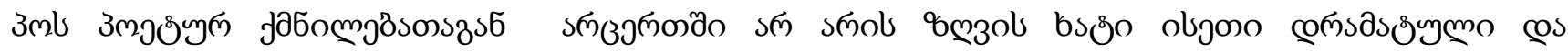

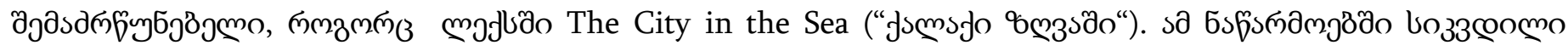

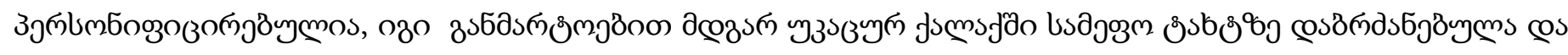

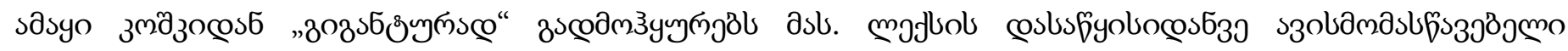

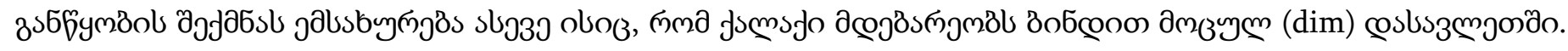

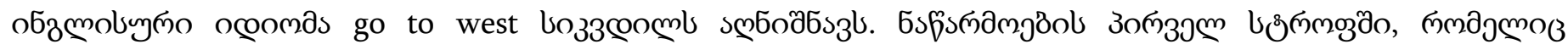

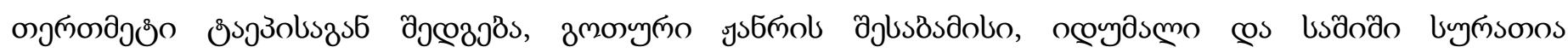

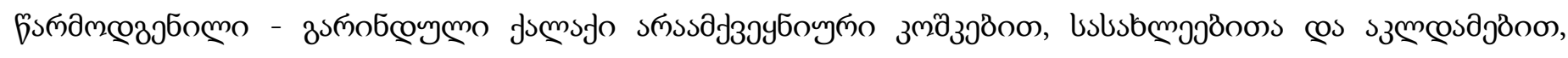

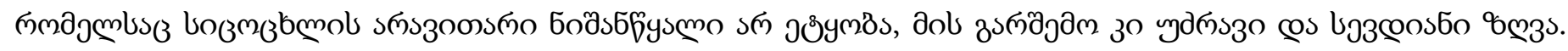




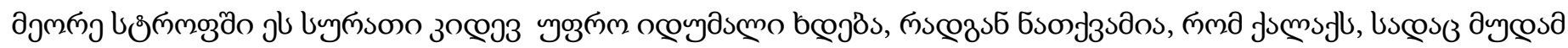

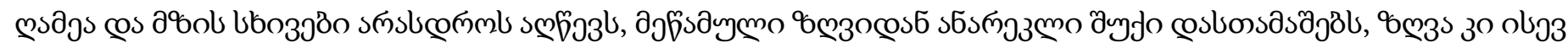

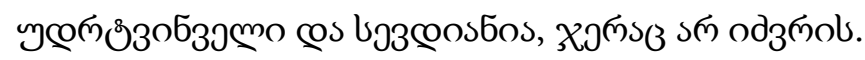

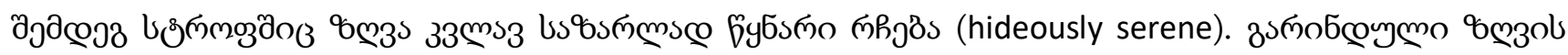

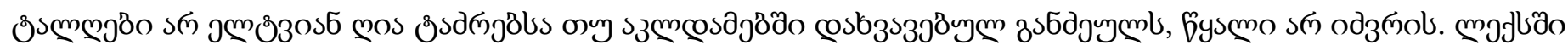

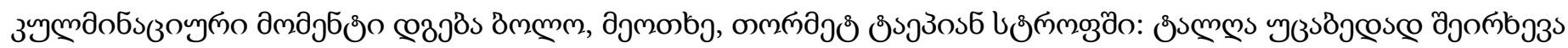

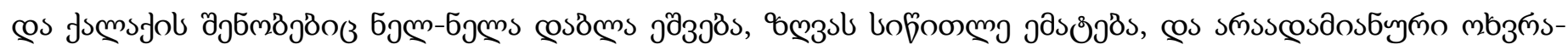

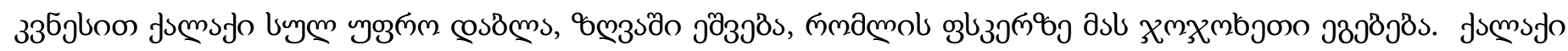

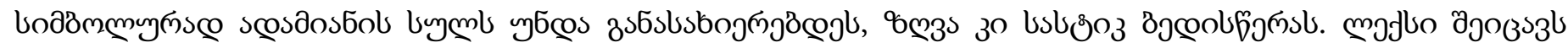

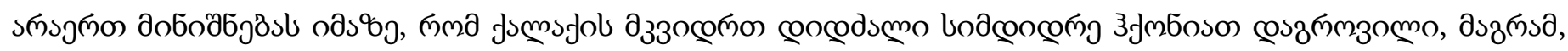

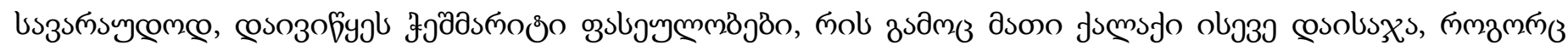

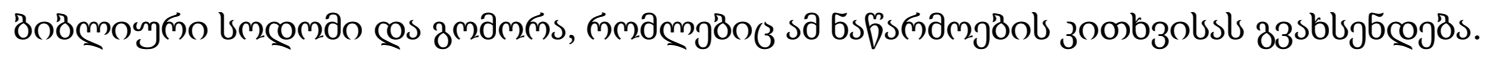

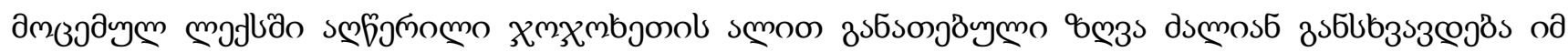

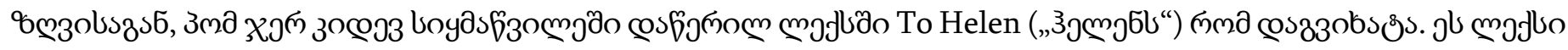

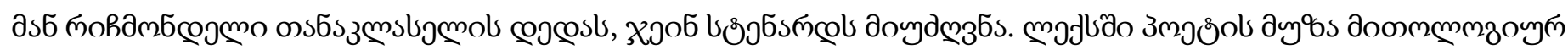

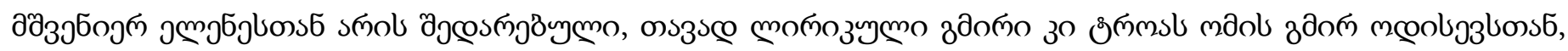

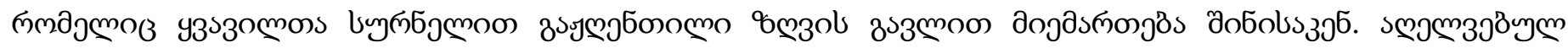

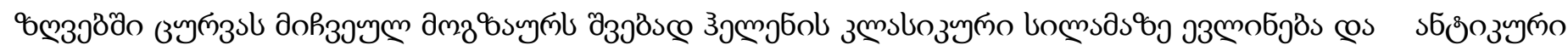

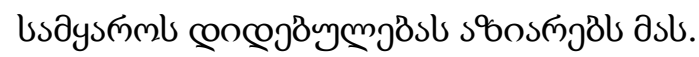

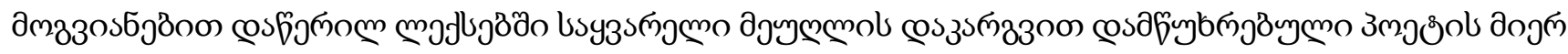

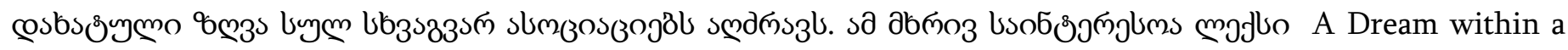

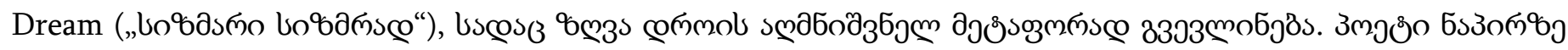

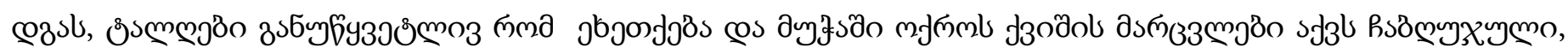

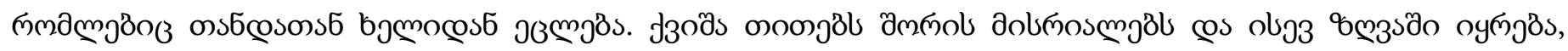

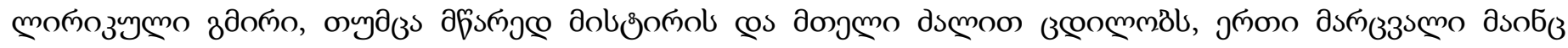

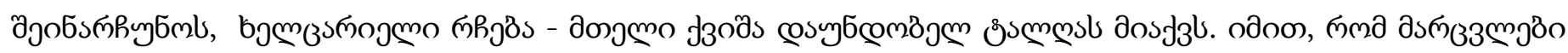

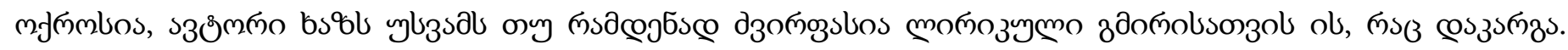

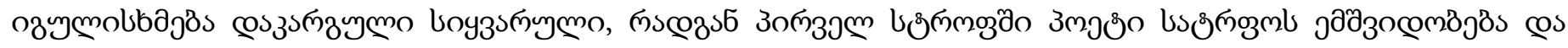

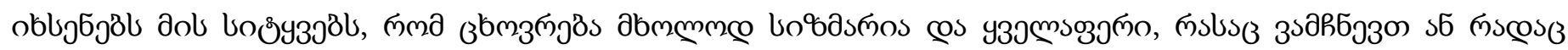

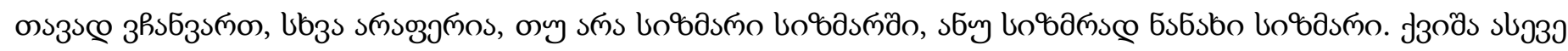

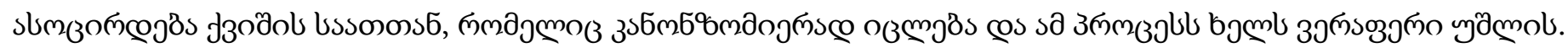

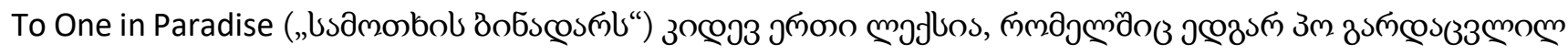

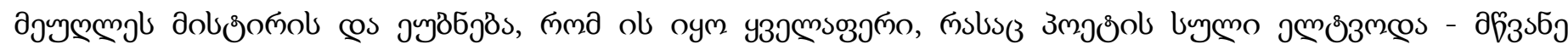

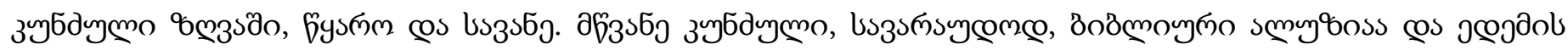

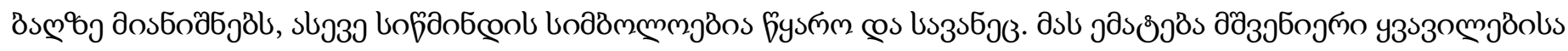

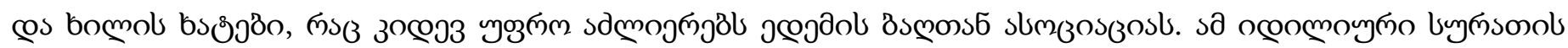

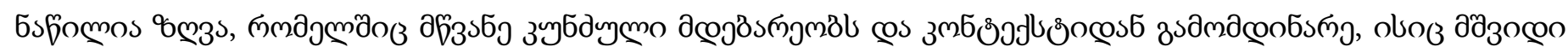




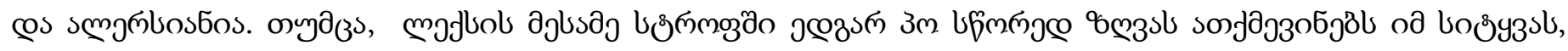

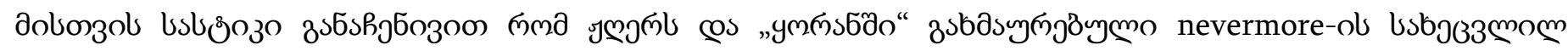

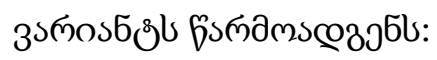

No more - no more - no more

(Such language holds the solemn sea

To the sands upon the shore)

Shall bloom the thunder-blasted tree,

Or the stricken eagle soar!

[ https://www.poetryfoundation.org/poems]

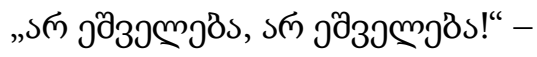

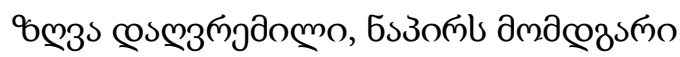

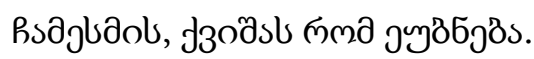

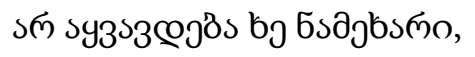

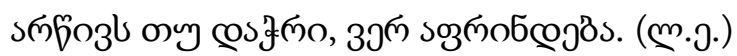

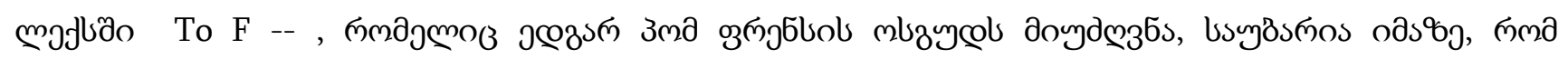

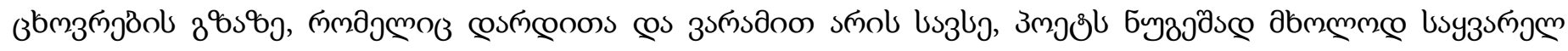

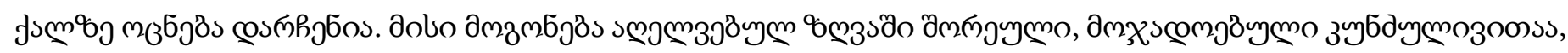

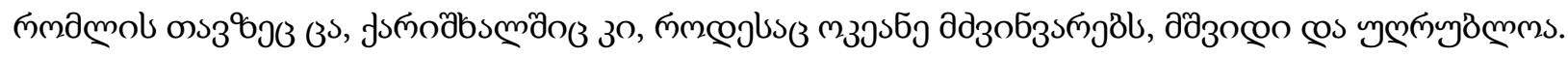

\author{
And thus thy memory is to me \\ Like some enchanted far-off isle \\ In some tumultuous sea - \\ Some ocean throbbing far and free \\ With storms - but where meanwhile \\ Serenest skies continually \\ Just o're that one bright island smile. \\ [https://www.eapoe.org/works/poems/francesb.htm]

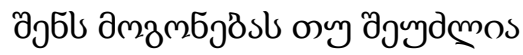

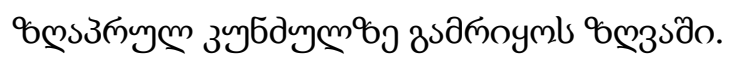

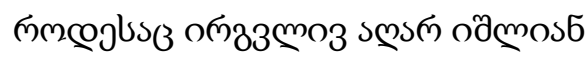

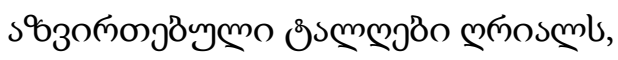

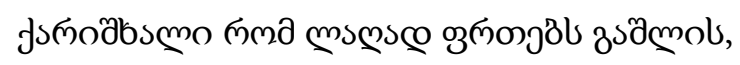

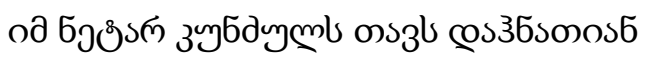

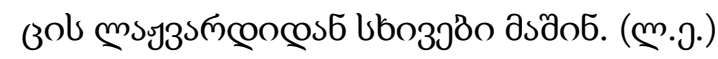

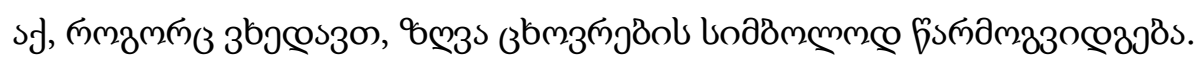




\section{$\cos _{33} 6 \mathrm{~s}$}

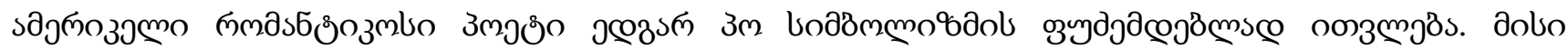

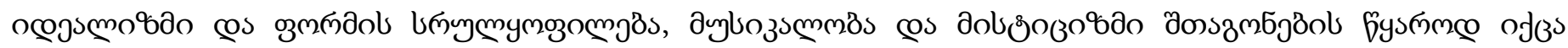

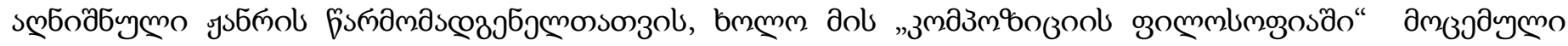

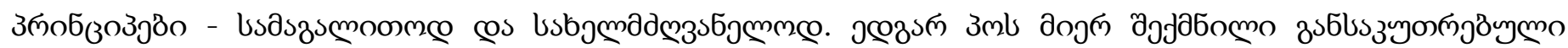

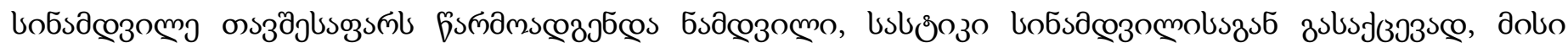

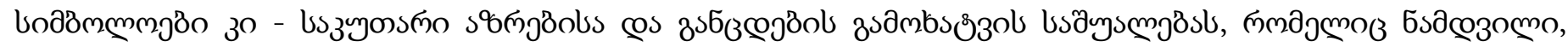

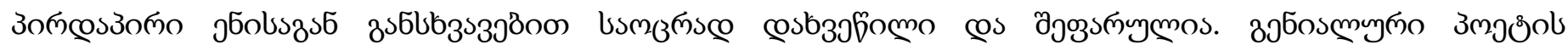

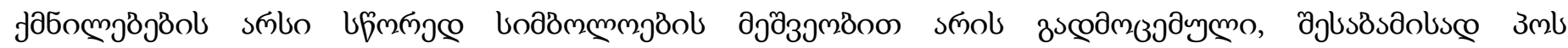

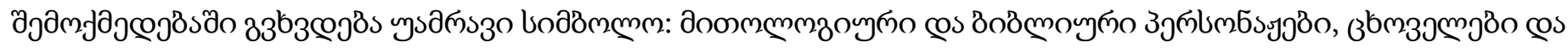

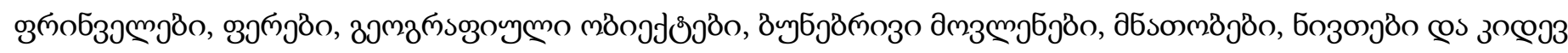
дпззьмо.

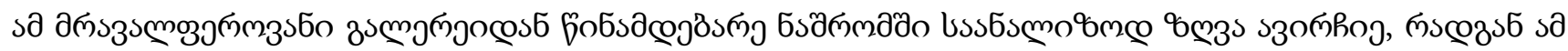

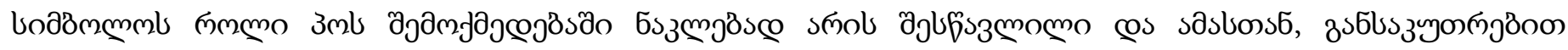

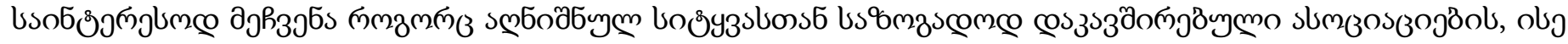

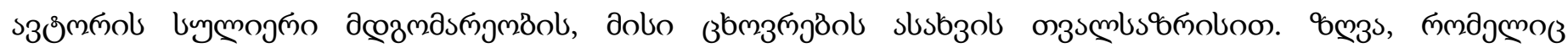

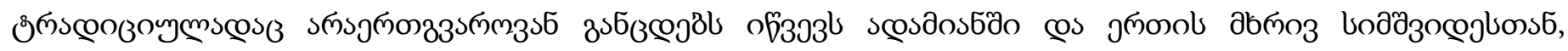

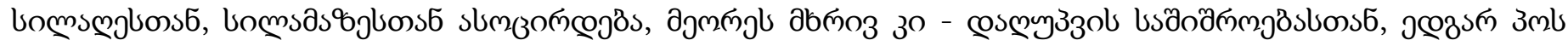

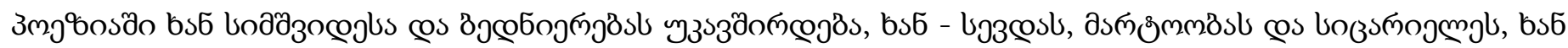

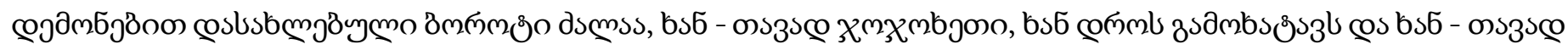

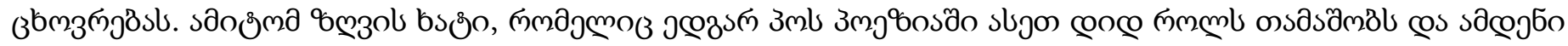

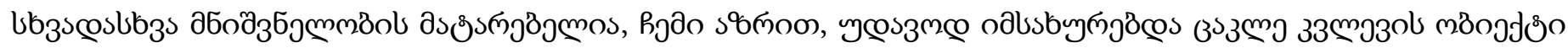

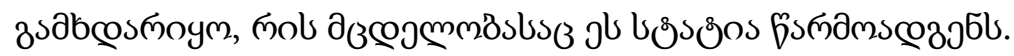




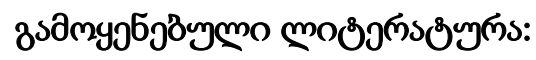

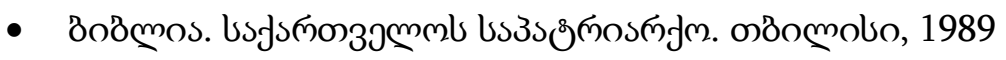

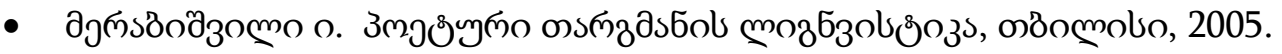

- Campbell R. Poems of Baudelaire, The Harvill Press, 1952

- Захаров В. Томашевский Б. An anthology of English and American Verse, 1972

- Huffman C. Myths Symbols Sandplay, https://mythsymbolsandplay.typepad.com/myblog/symbolism/ (28.02.2021)

- Phillips S. Symbolism and Poe, https://owlcation.com/humanities/Symbolismand-Poe $(11 / 13 / 21)$

- Shaw V. R. Nature Imagery in the Courtly Versions of the Tristan Legend, An Honors Thesis (ID 499), State University Muncie, Indiana April 1983

https://cardinalscholar.bsu.edu/bitstream/handle/handle/192482/S53 1983ShawVickieR.pdf?sequence=1\&isAll owed $=\mathrm{y}$

- Shakespeare W. The Tempest: Entire Play, https:/www.rsc.org.uk/the-tempest/the-plot (11/8/21).

- https://www.nosweatshakespeare.com/quotes/famous/sea-change/ (11/13/21)

- http://www.nplg.gov.ge/gwdict/index.php?a=term\&d=16\&t=3746 (11/13/21)

- https://www.yoair.com/ka/blog/under-the-sea-myths-and-legends-about-the-ocean-and-itscreatures/(11/13/21)

- https://www.eapoe.org/works/poems/francesb.htm 


\title{
Sea as a Multi-Meaning Symbol in Edgar Poe's Poetry
}

\section{Lela Ebralidze}

Ivane Javakhishvili Tbilisi State University

Assistant Professor, Doctor of Philology

https://orcid.org/0000-0003-0802-4085

\begin{abstract}
The present article aims at determining the symbolic meaning of sea in Edgar Poe's poetry. It deals with the essence of symbolism and symbols and is focused on Edgar Poe's contribution to symbolism as literary movement, as well as different symbols used in his poems. From a great number of symbols sea has been selected as a less-studied and multiple-meaning symbol. It has been examined in view of the traditional associations connected with it, also its usage in the Bible, mythology and literatures of different epochs. The article contains analysis of several poems by Edgar Poe where sea symbolizes very different things. It has been stressed that since Poe's works reflected his tragic life, the poet employed numerous symbols to express his own emotions, sea being one of them. In different poems, this symbol expresses the feelings that are very different and sometimes diametrically opposed to each other, and, respectively, acquires different meanings. With several other factors, its being a multi-meaning symbol became the main reason for choosing sea as an object of study.
\end{abstract}

Key words: symbolism, symbol, sea, poetry, multiple meaning 